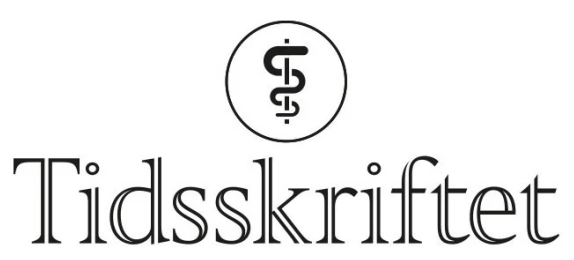

DEN NORSKE LEGEFORENING

\title{
Ja til grønnere pensum
}

DEBATT

\section{MATILLA FAREVÅG BERGER}

matillamberger@gmail.com

Matilla Færevåg Berger er sjetteårs medisinstudent ved Universitetet i Bergen og medlem av Legenes klimaaksjon.

Forfatteren har fylt ut ICMJE-skjemaet og oppgir ingen interessekonflikter.

\section{ELISABETH TRAN}

Elisabeth Tran er sjetteårs medisinstudent ved Universitetet i Bergen, tidligere leder av Klima=Helse og styremedlem i Legenes klimaaksjon.

Forfatteren har fylt ut ICMJE-skjemaet og oppgir ingen interessekonflikter.

\section{JOHANNE HEGDE}

Johanne Hegde er fjerdeårs medisinstudent ved Universitetet i Oslo og medlem av Legenes klimaaksjon.

Forfatteren har fylt ut ICMJE-skjemaet og oppgir ingen interessekonflikter.

\section{SARA SORAYA ERIKSEN}

Sara Soraya Eriksen er femteårs medisinstudent ved Universitetet i Bergen, tidligere folkehelseansvarlig i Norsk medisinstudentforening og styremedlem i Legenes klimaaksjon. Forfatteren har fylt ut ICMJE-skjemaet og oppgir ingen interessekonflikter.

\section{Klimakrisen er århundrets største trussel mot folkehelsen, og norsk helsesektor er en av de mest utslippsintensive i verden. Vi etterspør mer undervisning om klima og helse i legeutdanningen.}

Studentgruppen til nyoppstartede Legenes klimaaksjon har nylig foretatt en uformell kartlegging av hva norske medisinstudenter lærer om klima og helse. Funnene er forsvinnende få. E-postutveksling med fagansvarlige ved de fire medisinske fakultetene har avdekket at det i snitt foreligger kun én dobbelttime med forelesning på studiet som eksplisitt omhandler helsekonsekvenser av klimaendringer. Undervisningen inngår i samfunnsmedisin og global helse, og er ved tre av fire studiesteder lagt til femte studieår. Noen studiesteder tilbyr i tillegg prosjektoppgaver samt elektive emner der klima og helse er ett av temaene.

\section{Manglende kompetanse i grunnutdanningen}


Klimaproblematikk berører mange aspekter av medisinen (1), men blir altså ikke undervist på medisinstudiet før studentene nesten er ved veis ende. Skulle studentene få lyst til å lære mer, må de selv oppsøke relevante emner og prosjektoppgaver - forutsatt at de fra før vet at menneskeskapte klimaendringer er en trussel mot folkehelsen. Under utdanningen vektlegges det heller ikke at norsk helsevesen er blant de mest utslippsintensive i verden (2). Hvordan kan fremtidige norske leger være en del av utviklingen mot et klimanøytralt helsevesen, når det ikke undervises nok om hverken helsesektorens klimautslipp eller klimaendringenes helsekonsekvenser?

\section{Stort potensial i dagens studenter}

De yngre aldersgruppene anser i større grad klimaendringer som menneskeskapte enn eldre generasjoner, viser en rapport fra Cicero fra 2019 (3). I tillegg fremgår det at unge er mer opptatt av å endre egen adferd og mer villige til å støtte klimapolitikk enn de som er eldre enn 45 år, selv om engasjementet er økende også i eldre generasjoner.

At fremtidig helsepersonell er opptatt av klimaet, kommer også til syne i fagforeningen for norske medisinstudenter. På landsmøtet i 2020 vedtok Norsk medisinstudentforening en rekke grønne tiltak (4.). Tidligere har foreningen også etterlyst mer undervisning om helsekonsekvenser av klimaendringer (5).

\section{«Faktum er at helsepersonell i stor grad vil møte konsekvensene av klimakrisen $i$ sin arbeidshverdag $i$ årene som kommer»}

Det ligger derfor et stort potensial for klimaengasjement innen helse hos dagens studenter. I Tidsskriftets 15. utgave i 2020 skriver sjefredaktør Are Brean om det norske helsevesenets klimautslipp (므). Han etterspør en plan for å nå klimanøytralitet i helsesektoren. Skal helsesektoren bli klimanøytral, bør universitetene benytte seg av studentenes engasjement.

\section{Helsesektoren må henge med i utviklingen}

Klima og helse er fortsatt et nytt fagfelt. Den første professoren i verden i planetary health ble utnevnt i 2017 (7.). Vi har forståelse dersom undervisere ved landets medisinske fakulteter ikke føler seg kompetente nok til å forelese om dette temaet, men faktum er at helsepersonell i stor grad vil møte konsekvensene av klimakrisen i sin arbeidshverdag i årene som kommer ( $\underline{8})$. For å være rustet for dette er det helt essensielt at universitetene tør å satse, slik at fremtidens leger og andre studenter innen helsefag lærer om klima og helse allerede tidlig i studiet.

Studentgruppen til Legenes klimaaksjon planlegger å etablere lokallag ved de norske medisinske fakultetene. Vi ønsker å bidra til å bevisstgjøre studentene på sammenhengen mellom klima og helse og betydningen av bærekraftig medisinsk praksis. Både Norsk medisinstudentforening og Legenes klimaaksjon signaliserer gjennom egne initiativer at studentene $\emptyset$ nsker å øke fokuset rundt dette på veien mot nullutslipp. Men vi klarer det ikke alene. Hvor er initiativet fra høyere hold?

Alle samfunnets sektorer må ta del i prosessen med å motarbeide klimaforandringene dersom vi skal klare å nå klimamålene fra Paris-avtalen (모). Vi ser det som en selvfølge at også helsesektoren må gjøre sin del. Dette er en utvikling vi ønsker å være en del av. Derfor etterspør vi mer undervisning om helsesektorens klimautslipp og om hvordan folkehelsen trues av klimaforandringene. 


\section{LITTERATUR}

1. Costello A, Abbas M, Allen A et al. Managing the health effects of climate change. Lancet 2009;373: 1693-733. [PubMed][CrossRef]

2. Health care without harm. Health care climate footprint report. https://noharmeurope.org/ClimateFootprintReport Lest 16.11.2020.

3. Aasen M, Klemetsen M, Reed EU et al. Folk og klima: Nordmenns holdninger til klimaendringer, klimapolitikk og eget ansvar. Oslo: Center for International Climate Research (CICERO), 2019. https://pub.cicero.oslo.no/ciceroxmlui/bitstream/handle/11250/2634149/Rapport\%202019\%2020\%20HQweb.pdf? sequence $=6 \&$ isAllowed $=y$ Lest 16.11 .2020 .

4. Moe L. Medisinstudentene har vedtatt flere grønne tiltak. Dagens medisin 24.8.2020. https://www.dagensmedisin.no/artikler/2020/o8/24/medisinstudentene-har-vedtatt-flere-gronnetiltak/ Lest 16.11.2020.

5. Bruholt E. Medisinstudentene vil ha klimaendring på pensum. Dagens medisin 20.2.2020. https://www.dagensmedisin.no/artikler/2020/02/20/medisinstudentene-vil-ha-klimaendring-papensum/ Lest 16.11.2020.

6. Brean A. Helseskadelige helseutslipp. Tidsskr Nor Legeforen 2020; 140. doi:10.4045/tidsskr.20.0830. [PubMed][CrossRef]

7. Kirby T. Tony Capon: the world's first professor of planetary health. Lancet 2018; 391: 21. [PubMed] [CrossRef]

8. Watts N, Amann M, Arnell N et al. The 2019 report of The Lancet Countdown on health and climate change: ensuring that the health of a child born today is not defined by a changing climate. Lancet 2019;394: 1836-78. [PubMed][CrossRef]

Publisert: 9. februar 2021. Tidsskr Nor Legeforen. DOI: 10.4045/tidsskr.20.0964

Mottatt 24.11.2020, første revisjon innsendt 21.12.2020, godkjent 11.1.2021.

(C) Tidsskrift for Den norske legeforening 2023. Lastet ned fra tidsskriftet.no 26. april 2023. 